DOI: https://doi.org/10.33739/2587-5434-2021-3-1-52-60

\title{
AFFIXES PRODUCING "LOCAL-SPATIAL" WORD-BUILDING MEANINGS IN THE GERMAN LANGUAGE
}

\author{
Irina Kruashvili \\ Doctor of Philology, Associate Professor \\ Sokhumi State University \\ (Tbilisi, Georgia) \\ e-mail: i.kruashvili@sou.edu.ge
}

\begin{abstract}
Annotation. The aim of the article is to show which word-building affixes take part in the formation of local-spatial meanings in the German language; to describe the derivational models produced with the use of the mentioned affixes and to characterize their structural and semantic peculiarities; to discuss formal and contentual characteristics of derivational affixes, including suffixes and prefixes; to determine statistical data of word-building constructions having local-spatial importance and to compare the frequency of their use in texts of various kinds.

We use several methods of research in the article, namely, immediate constituent analysis (IC Analyse), methods of description, opposition, transformation and substitution. By means of these methods, it becomes possible to elaborate appropriate structural-semantic criteria as well as description and modelling of the types of word-building constructions.

Results of the research can be characterized as follows: both suffix and prefix derivatives serve to the expression of the local-spatial word-building semantics in the German language. We have analyzed up to 100 word building constructions, which express nuances of the mentioned meaning; we have discussed separately affixes producing nouns, adjectives and verbs. Along with the multitude of the ways of production, the complex words are also characterized by the diversity of root components; namely, in suffix and prefix derivatives, there occur nouns, adjectives, verbs and adverbs in the capacity of root words.

From the materials discussed in the article, there can be drawn a conclusion that derivatives expressing local-spatial word-building semantics occupy an important place in the lexical system of the German language. Their many-sided use with attributive, predicative and adverbial functions attest the role of wordbuilding constructions beside the syntagma and simplex. Word-building affixes producing local-spatial semantics make a great contribution to the realization of general tendencies of the development of modern German language, which, above all, is true for the sphere of syntax.
\end{abstract}

Keywords: word-building meaning, prefix, suffix, derivation.

\section{«ЛОКАЛЬНО-ПРОСТРАНСТВЕННЫЕ» СЛОВООБРАЗОВАТЕЛЬНЫЕ АФФИКСЫ В НЕМЕЦКОМ ЯЗЫКЕ}

\author{
Ирина Круашвили \\ Доктор филологии, ассоциированный профессор \\ Сухумский Государственный Университет \\ (Тбилиси, Грузия) \\ e-mail: i.kruashvili@sou.edu.ge
}

\begin{abstract}
Аннотация. Цель статьи - показать, какие словообразовательные аффиксы участвуют в формировании локально-пространственного словообразовательного значения в немецком языке; описать деривационные модели с участием этих аффиксов и охарактеризовать их структурносемантические особенности; рассмотреть формальные и семантические параметры деривационных аффиксов, как суффиксов, так и префиксов; определить статистические данные
\end{abstract}


словообразовательных конструкций с локально-пространственным словообразовательным значением и обобщить частотность их употребления в различных видах текстов.

В статье мы используем несколько методов исследования, а именно, анализ по непосредственно составляющим, описательный, сопоставительный, трансформационный и субституционный методы. С их помощью становится возможным выработать нужные структурносемантические критерии, описать и смоделировать разновидности словообразовательных конструкций.

Результаты исследования можно охарактеризовать следующим образом: выражением локальнопространственного словообразовательного значения в немецком языке служат как суффиксальные, так и префиксальные производные слова. Мы проанализировали до 100 словообразовательных конструкций, выражающих различные нюансы вышеупомянутого значения; По отдельности рассмотрели субстантивные, адъективные и вербальные словообразовательные аффиксы. Помимо разнообразия словообразовательных методов, сложные слова характеризуются еще и разнообразием производящих основ, а именно, в суффиксальных и префиксальных производных словах в качестве производящих основ выступают существительные, прилагательные, глаголы, наречия.

Из рассмотренного в статье материала можно сделать вывод о том, что производные слова с локально-пространственным словообразовательным значением занимают важное место в лексической системе немецкого языка. Их универсальность в атрибутивной, предикативной и адвербиальной функциях подтверждает важную роль упомянутых словообразовательных конструкций наряду со словосочетанием и симплексом. Словообразовательные аффиксы с локальнопространственным словообразовательным значением в значительной степени способствуют реализации общих тенденций развития немецкого словарного запаса, что особенно заметно в синтаксической области.

Ключевые слова: словообразовательное значение, префикс, суффикс, деривация.

INTRODUCTION. In order to express local-spatial word-building semantics, there occur both compositional and derivational models in the German language. We shall discuss in the present article the word-building affixes that have more or less clearly expressed local meanings, or which participate in the formation of the mentioned semantics. German suffixes stand out by wide spectrum of meanings. It cannot be asserted that they express only local relations. What about the majority of prefixes analyzed by the authors of the present paper, they contain the mentioned sema independently, too. In periphrasis, there are mainly used local-situational prepositions. The function of the first direct constituent is to express place. The first constituent can express direction, too, which is given explicitly in terms of morphology. The article discusses expressly and separately concrete aspects and examples connected to each one of the prefixes.

REVIEW OF THE ISSUE. Many papers have been devoted to the topics of word building in the German language; they have explored complex words, as well as have established rules and models, according to which there occurs the production of word-building constructions. With the flood of new words in the language, one of the most topical problems of the German linguistics is now to describe meanings and functions of complex lexical units. Topicality of the problem conditions the intensive research of the issues connected to it.

We use papers of German linguists and lexicographers in the present article. Out of many scientists, whose concepts and theoretical opinions were shared in the present article, we must name works of Fleischer/Barz, Elsen, Kühnhold/Putzer/Wellmann, Donalies, Bittner, Eisenberg, Inghult, Seibicke and others. Derivatives with local-spatial word-building semantics are retrieved from 
dictionaries as well as from artistic, social-political and technical texts. The analyzed materials are double-checked in newest online dictionaries.

METHODS OF RESEARCH. Methods of research used in the article comply well with the object of discussion, and show forth its regularities and peculiarities. We are using various methods of research in the present paper, namely, IC-Analyse, methods of description, opposition, transformation and substitution. With their optimal use, it becomes possible to ascertain structural, semantic and pragmatic parameters of derivatives having local-spatial word-building semantics.

RESULTS AND DISCUSSION. We shall start discussing this matter with German suffixes that produce derivatives, where there can be distinguished the local-spatial sema.

The suffix -ig is one of the most widespread and productive adjectival affixes in the modern German language, and derivatives produced by means of it amount to hundreds. It is called a certain universal suffix, due to the fact that it binds various roots and participates in almost all kinds of word-building patterns.

As a rule of thumb, derivatives with -ig suffix keep the meaning of the root word. Using the suffix -ig, mainly, the meaning of the root word is used to determine other linguistic features by means of attributive or predicative functions. Derivatives mostly express physical or spiritual features of humans or denominate characteristic signs for objects or phenomena. Such constructions are often produced from nominal composites: ein kahlköpfiger Greis, ein schwermütiger Blick.

Among the derivatives with -ig suffix, there can be distinguished ornative, comparative, temporal and other word-building meanings (Kruashvili 2013: 136), but we shall not discuss them as they do not represent the object of our research. We shall deal with word-building constructions produced by local adverbs such as hiesig, dortig, jenseitig. In these cases adverbs become flexional and derivatives are used attributively. Semantic changes do not occur, derivatives express localspatial word-building meanings: hiesiger Gemeinderat, dortige Vorkommnisse, jenseitiges Ufer.

If in the adverbial root the last consonant is $-s$, it shall be elided before the suffix -ig: abseits abseitig, rückwärts - rückwärtig. The root can undergo other changes, too, namely, to lose the vowel -e: oben - obig.

The next suffix that participates in the formation of local-spatial word-building semantics in the sphere of adjectives, is -mäßig. Amongst the derivatives with the suffix -mäßig, there exists a wide spectrum of semantic meanings, which consists of several groups. The groups are close relatives to each other. To distinguish separate meanings, specific interpretation and relationship with context should be taken into consideration. We have become familiar with works by Seibicke, Inghult, Kühnhold/Putzer/Wellmann, Bittner, Fleischer/Barz as well as those of other linguists in connection with the suffix -mäßig, where the authors suggest different semantic categories. At the same time, they recognize that the uniform ascertainment of mentioned semantic categories is often connected with difficulties without the context. Three principal word-building meanings, namely, comparison, restriction and conformance are given in almost all the studies, and the rest do not overlap. E.g., Kühnhold/Putzer/Wellmann additionally suggest the "word-building examples" expressing the kind of action, identity and tool/instrument (Kühnhold/Putzer/Wellmann 1978, 115), with Inghult, we additionally encounter the semantic categories denoting form, cause and means (Inghult 1975, 50). 
What about the local meaning or the meaning expressing place, it is registered with the suffix -mäßig only by Bittner. Bittner expressly discusses the mentioned word-building meaning. To illustrate this idea, she gives propositions, where the derivative with the suffix -mäßig indicates the place or the phenomenon which can be determined according to the place:

1) Arbeitsplatzmäßig sieht es da schlecht aus (Am Arbeitsplatz sieht es da schlecht aus).

2) Ich mag es nicht, so faschingsmäßig daherzulaufen. (Ich mag es nicht, so wie im Fasching daherzulaufen).

3) Man hat labormäßig schon Flaschen mit bis zu 10 bar belastet. (Man hat im Labor schon Flaschen mit bis zu 10 bar belastet).

4) ... das CD-Rom wird einfach peripheriemäßig angeschlossen. (... das CD-Rom wird einfach an die Peripherie angeschlossen).

5) Tanja S. war wettkampfmäßig ein halbes Jahr lang nicht mehr auf dem Eis. (Tanja S. war bei Wettkämpfen ein halbes Jahr lang nicht mehr auf dem Eis).

6) Wettkampfmäßig kamen wir (Olaf Ludwig und XY) nie recht zusammen. (Bei Wettkämpfen kamen wir (Olaf Ludwig und XY) nie recht zusammen). (Bittner 1996, 14).

According to the third proposition, the bottles were loaded in the laboratory; in the fifth and sixth propositions competition represents to us the place where Tanja S. has not been for a long time already and where Olaf Ludwig and XY have never met each other. The author discusses the competition as a place. Here it is dealt with an event that is held in a certain place at a certain time. The author perceives the carnival as a certain place. "Shrovetide" or "Fasching" has its defined place at a certain time of the year.

Bittner writes that the local meaning is especially clearly revealed when we compare the suffix -mäßig with the suffix -haft:

a)

ettkampfmäßig kamen wir (O. Ludwig und XY) nie recht zusammen.

b)

ettkampfhaft kamen wir (O. Ludwig und $X Y$ ) nie recht zusammen.

This opposition makes clear for us that: a) not the character of meeting in a sentence, but the place represents the principal meaning of the derivative root. Hence, b) the sentence is grammatically incorrect.

In Bittner's opinion, we shall find difficulties during the characterization of the fourth sentence if we do not use the "local" interpretation. Compact disc, indeed, can be connected only to the periphery and not "as periphery" or "by periphery" (Bittner 1996, 15).

If we use the word arbeitsplatzmäßig anywhere else apart from the above-mentioned sentence (1), e.g., Die arbeitsplatzmäßigen Verbesserungen sind von der Direktion abgesegnet worden., or: Die Arbeit in der Druckerei ist arbeitsplatzmäßig eine echte Verbesserung., - we shall see that here arbeitsplatzmäßig does not imply the workplace (Arbeitsplatz) in terms of occupation, but the workplace as a concrete place where the work occurs. The initial meaning of Arbeitsplatz in sentence (1) is metaphorical. Thus, here the meaning returns to the sphere of concretics again. In both cases the problem is created by the circumstance that arbeitsplatzmäßig expresses restriction, too. This problem is especially well revealed during an adverbial use. Yet, if we substitute the sentence Die arbeitsplatzmäßigen Verbesserungen sind von der Direktion abgesegnet worden. _ with the sentence _ Die Verbesserungen des Arbeitsplatzes sind von der Derektion abgesegnet worden., _ then it shall become clear that the derivative with the suffix -mäßig binds to genitivus 
loci, which, of course, must express always constriction; yet, as the constriction is contained in each extrapolation or concretization, it cannot be regarded as a differentiating sign. As we can see, there exists a convincing argumentation in derivatives with the suffix -mäßig in order to distinguish localspatial word-building meanings.

Suffixes of nouns also take part in the formation of the local-spatial word-building semantics.

The suffix $-e$, when appended to the verbal root, produces derivatives in which there can be distinguished the local sema: Bleibe, Kippe, Schwemme. Nouns with the suffix -e connect to the action expressed by the root verb, e.g., Anrichte (Geschirrschrank mit einer Fläche zum Anrichten $u$. Bereitstellen der Speisen; Büfett) (DUW 2015, 158) is a place, more specifically, a piece of furniture where the dishes are placed; Umkleide (eine Kabine, in der man sich (etwa zum Baden oder Sporteln) umkleidet) (Donalies 2005, 102) is a cabin where people change clothes (for swimming or for other sportive activities).

The suffix -ei binds simplex or complex roots: Pfarrei, Detektei. Derivatives with the suffix $e i$ express the place which is used to store an object denoted by a root noun or to produce it: Kartei, Ziegelei, Bücherei, Gärtnerei.

The suffix -schaft is etymologically linked to the verb schaffen, or ancient upper-Germanic scaffan, older ancient upper-Germanic -scaft (Kluge 2011, 86). It is mainly connected to the semantics of persons: Studentenschaft, Mannschaft, Dienerschaft. Yet, when the root word is not a denomination of persons, then there is expressed the local-spatial word-building meaning: Dorfschaft, Ortschaft, Landschaft, Grafschaft.

One of the most productive suffixes for nouns, -ung can also denote place, though this is not the principal word-building meaning for derivatives with -ung suffix. In the Reverse Dictionary Muthmann (Muthmann 2011) there are registered up to 10000 derivatives with -ung suffix. It produces nouns mainly from verbs. Derivatives with the suffix -ung express processes, state, actions or their results. The local-spatial word-building meaning is expressed in such compounds as Abteilung, Ansiedlung.

Foreign or borrowed suffixes: -ade (Promenade), -arium (Planetarium), -at (Konsulat, Notariat), -erie (Drogerie) (Elsen 2011, 98) also take part in the expression of the local wordbuilding meaning, though the number of derivatives produced by them is small.

Now let's characterize prefixes. In order to produce local-spatial word-building meanings, in the spheres of nouns and adjective there are used the foreign prefixes: ex-, inter-, para-, sub-, transin the German language.

The prefix $e x$ - originates from the Latin language. It is characterized for almost unchangeable function for more than 200 years already. Origin of the prefix $e x$ - as a productive affix is connected to the abolishment of the Order of Jesuits by the Roman Pope Clement XIV in 1773. Members of this Order, possessing quite considerable political influences, have lost their positions in some European countries even before that. Ex-Jesuit denoted a man, whose social status had been radically shattered. This word has spread from chancelleries into the general political vocabulary and there have appeared analogical compounds: Exgeneral, Exminister (Eisenberg 2013, 239). The prefix ex- most frequently is connected with the denomination of persons and denotes "past, former": Expräsident, Exbürgermeister. This time, we are interested in another function of the prefix $e x$-, where the spectrum of its meanings has been slightly altered. In this case it denotes being out of the boundaries of something (aus, heraus): exterritorial, extern, Externat, Ex-DDR, exzentrisch, exogen. 
The prefix inter-denotes a spatial disposition-orientation between the notions (zwischen "between"). It usually binds suffix derivatives with foreign roots and is quite widespread: interparlamentarisch. It occurs especially often in natural scientific, technical and medical terminology: interplanetarisch, intergalaktisch, interkontinental, interstellar, interdental, intermolekular.

The prefix para- originates from Greek and expresses spatial relationship (neben and in der Umgebung von - "beside", "near"); it mainly occurs with nouns and adjectives having foreign roots, which pertain to the terminological vocabulary: paranasale Entzündung, Paramedizin, paranormal, parapsychisch.

The prefix $s u b$ - originates from Latin and expresses social subordination (unterhalb von). It mainly binds the suffix derivatives with foreign roots, which pertain to the terminological vocabulary. Namely, in the geographical terminology, the prefix $s u b$ - is used to express direct vicinity to a certain climatic zone: Subtropen, subalpin, subalpinisch, subarktisch, subantarktisch, subpolar, subtropisch.

The prefix trans- also originates from the Latin language (über, durch, hinaus, jenseits - "in", "between", "through", "beyond"). It mainly occurs in deverbal derivatives or binds the derivatives with -isch suffix, which have foreign words as the root. The prefix trans- expresses spatial orientation and occurs in geographical names: Transkaukasien, transatlantisch, Transjordanien, Transbaikalien, transcontinental, transalpinisch, transalpin, translunarisch, translunar, transuranisch.

inter- and trans- have oppositional relationships to each other: internationale Verhandlungen - transsibirische Eisenbahn, interdisziplinäre Forschung - transuranische Elemente.

Constructions with inter- and trans- prefixes Fleischer/Barz consider as combinatory derivatives, as they form adjectives together with certain suffixes. For instance, inter...-al international (Fleischer, Barz 2012, 375). At the same time, they, too, emphasize the fact that these constructions do not connect to the substantive root semantically when there exists a desubstantive adjective: interkontinental is zwischen den Kontinenten and not inter + kontinental (ibid.). If we follow this logics, then the majority of prefix derivatives should be considered to be combinatory derivatives, as in German words very frequently prefix and suffix act simultaneously. E. g., erzreaktionär, uramerikanisch, prowestlich, disproportional, antiwestlich. Yet, Fleischer/Barz do not consider them to be combinatory derivatives. In our opinion, while classifying derivatives, there must be deemed as an initial criterion the fact, whether this or that suffix derivative exists as an independent adjective without the prefix: unappetitlich $=u n+$ appetitlich, transsibirisch $=$ trans + sibirisch. We consider such constructions to be prefix derivatives.

The local-spatial word-building meaning occurs in German verbal derivatives, too. Prefixation is one of the most frequently used word-building methods in the sphere of verbs. Prefix derivatives considerably enrich the category of verbs with their semantics and syntax modifications. They can convey differentiation of meanings, and express different nuances.

Intransitive verbs with ent- prefix express "distancing/moving far away" from the subject, and transitive verbs, that from the object: entgehen, entkommen, entfernen. In such verbs as entführen, entfliehen, entweichen, entfallen, entreißen, the root word itself expresses distancing, and the prefix -ent gives perfect tense meanings to the word-building constructions. We can discuss derivatives with -ent and -aus prefixes as synonymic compounds: entströmen/ausströmen, entleihen/ausleihen, 
entladen/ausladen. Yet, in the mentioned couples the verbs with ent- prefixes are stylistically marked and suffer more restrictions in terms of usage.

The main function of the verbs with $-a b$ prefix is to express distancing between two values: absteigen.

The prefix -an binds a verbal root. Derivatives point to the direction of the action expressed by the root verb towards an object. Root verbs can be grouped semantically, namely, verbs expressing vision/watching: jemanden anblicken, anschauen, anblinzeln, anglotzen, angrinsen, anlachen, anstaunen; verbs expressing the manner of talking: jemanden ansprechen, anbrïllen, anflehen; verbs expressing movement: etwas anfahren, anfliegen, ansegeln, ansteuern, etc.

The prefix auf-expresses the direction "upwards" (nach oben). It is connected to the verbs, the semantics of which, to a certain extent, influences the formation of various nuances of the localspatial word-building meanings of the whole derivative: aufblicken, aufsehen, aufschauen, aufspringen, aufprallen, aufheben. The verb aufstehen represents a demotivated compound.

The prefix -aus modifies simple, less frequently, complex verbs and points to the direction "from inside to the outside," "outwards" (aus etwas heraus). Mainly, verbs expressing movement serve as roots: aussteigen, ausreisen, auswandern, ausweisen, ausfahren, ausgehen, ausmarschieren, ausreiten. Direct constituents of the composites, hinaus and heraus, have a closely relative word-building meaning, but as distinct from the composites, verb derivatives with the prefix aus- are characterized by restrictions and specifics in terms of usage. They occur only in certain context and, apart from the local meaning, convey other additional semantic tints either. Compare: hinausgehen - to go out (e.g., out of the room) and ausgehen (to go somewhere, to go out of the house with certain aims).

CONCLUSION. As we can see, in order to express the local-spatial word-building semantics, there are used both suffix and prefix derivatives in the German language. Derivatives with -ig and -mäßig suffixes are pure local adjectives. The same is true for nouns with $-e$ and $-e i$ suffixes. They point to this or that concrete place in a narrow sense, and what about the compounds with ex-, inter-, para-, $s u b-$, trans- prefixes, they are connected to notions having wider scales. As distinct from suffixes $-e$, -ei, -schaft, -ung, -ig and -mäßig, the prefixes such as ex-, inter-, para-, sub-, trans-, auf-, auscontain into themselves the semantic nuance of place, namely, inter- denotes "between", trans"in", "between", para- _ "beside", "near", sub- _ "beneath", ex- "out of the boundaries of something", auf- _ "upwards" and aus- _ "outwards". Yet, despites the fact that they express different locations/places, all the mentioned affixes imply 'unity of slightly differing items.' They serve to the expression of a local-spatial relationship.

\section{LIST OF REFERENCES}

Bittner, D. (1996). Die Adjektivbildungen auf -mäßig im Gegenwartsdeutsch. [Adjectival wordbuilding compounds ending in -mäßig in the modern German language]. Freiburg.

Donalies, E. (2005). Die Wortbildung des Deutschen. Ein Überblik [Word-building of the German. Overview], Tübingen, "Günter Narr Verlag".

DUW - Duden (2015). Deutsches Universalwörterbuch [German Universal Dictionary], Berlin, "Dudenverlag". 
Eisenberg, P. (2013). Grundriss der deutschen Grammatik. Das Wort. [Principal strokes of the German Grammar. The Word], Vol. 1, Stuttgart, Weimar, "Metzler".

Elsen, H. (2011). Gründzüge der Morphologie des Deutschen. [Principal strokes of morphology of the German], Berlin/Boston, "Walter de Gruyter".

Fleischer, W./Barz, I. (2012). Wortbildung der deutschen Gegenwartssprache [Word-building of the modern German language], Berlin/Boston, „De Gruyter”.

Inghult, G. (1975). Die Semantische Struktur desubstantivischer Bildungen auf -mäßig. Eine synchronisch-diachronische Studie. [Semantic structure of desubstantive compounds ending in mäßig. Synchronic-diachronic research]. Stockholm, „Almqvist och Wiksell““.

Kluge, F. (2011). Etymologisches Wörterbuch der deutschen Sprache. [Etymological Dictionary of the German Language], Berlin, Verlag "Walter de Gruyter".

Kruashvili, I. (2013). Zedsarthauli sitkvatsarmoebithi konstruqtsiebis tsarmoqmnis tendentsiebi germanul enashi [Tendencies of the nascence of adjectival word-building constructions in the German language], Tbilisi, "Universali”.

Kühnhold, I., Putzer, O., Wellmann, H. (1978): Deutsche Wortbildung. Typen und Tendenzen in der Gegenwartssprache. 3. Hauptteil. Das Adjektiv. [German word-building. Types and tendencies in the modern language. The 3rd principal part. Adjective]. Düsseldorf, „Pädagogischer Verlag Schwann“.

Muthmann, G. (2011). Rückläufiges Deutsches Wörterbuch. Handbuch der Wortausgänge im Deutschen, mit Beachtung der Wort- und Lautstruktur [Reverse Dictionary of the German Language. A compendium of Present-day vocabulary considering the morphological and phonological structure of the words]. Berlin, „Walter de Gruyter“.

Seibicke, W. (1963). Wörter auf „--mäßig“. Sprachkritik und Sprachbetrachtung. [Words ending in „-mäßig“. Linguistic criticism and linguistic review]. In: Muttersprache 2/73, P. 33-47.

Wahrig (2008). Deutsches Wörterbuch [German Dictionary]. Gütersloh/München, "Bertelsmann”. https://www.duden.de/woerterbuch [12.02.2021].

https://www.duden.de/rechtschreibung/online [09.02.2021].

\section{For citation:}

Kruashvili, I (2021). Affixes producing "local-spatial" word-building meanings in the German language // International Scientific-Pedagogical Organization of Philologists "WEST-EAST " (ISPOP). Scientific Journal WEST-EAST. Vol 5 N1 (March, 2021). pp. 52-60. https://doi.org/10.33739/2587-5434-2021-3-1-52$\underline{60}$

\section{Для цитирования:}

Круашвили, И. (2021). «Локально-пространственные» словообразовательные аффиксы в немецком языке // International Scientific-Pedagogical Organization of Philologists “ WEST-EAST ” (ISPOP). Scientific Journal WEST-EAST. Vol 5 N1 (March, 2021). C. 52-60. https://doi.org/10.33739/2587-54342021-3-1-52-60

\section{Information about the author:}

Irina Kruashvili - PhD, associate Professor for German linguistics at Sokhumi State University (Tbilisi), Scholarship holder of the DAAD and the Goethe-Institut, member of the Senate of Sokhumi State University, member of the German Teachers ' Association in Georgia (DVG), member of the International 
Association for German Studies (IVG), author of more than 50 scientific publications in German, English, Russian and Georgian. (Georgia).

e-mail: i.kruashvili@sou.edu.ge

\section{Сведения об авторе:}

Ирина Круашвили - Доктор филологии, ассоциированный профессор Сухумского Государственного Университета (Тбилиси), стипендиат DAAD и Гете-Института, член Сената при Сухумском Государственном Университете, член Ассоциации Учителей Немецкого Языка в Грузии (DVG), член Международной Ассоциации Германистики (IVG), автор более 50 научных публикаций на немецком, английском, русском и грузинском языках. (Грузия).

e-mail: i.kruashvili@sou.edu.ge

Manuscript received: 15/01/2021

Accepted for publication: $14 / 02 / 2021$

Рукопись получена: 15/01/2021

Принята к печати: 14/02/2021

\section{International Scientific-Pedagogical Organization of Philologists "West-East" ISPOP SCIENTIFIC JOURNAL "WEST-EAST" ISSN (print) - 2587-5434 ISSN (online) - 2587-5523}

